\title{
Faglig dyktig, sa du?
}

Hva vil det si å være faglig dyktig? Svaret er ikke gitt. Hva vi definerer som faget og hvilke kvaliteter en faglig dyktig lege skal inneha, røper mye om oss selv.

Hertzberg og medarbeidere skrev i Tidsskriftet nr. 19/2016 om hvordan leger selv definerer en god lege som en kollega med sterk faglig dedikasjon (1). Hva vi hevder faget og faglig dyktighet er, definerer vår profesjon innad og for omverdenen. Den til enhver tid herskende oppfatningen om faglig dyktighet, særlig blant kolleger, indikerer noe om minst tre ting: hva medisinen $e r$, hva den $b ø r$ være og hva vi som leger krever av oss selv. Slik avslører fagligheten oss.

Hvilke kvaliteter innehar en faglig dyktig lege? Noen vil hevde at minste felles multiplum er at hun vet hva som står i bøkene om diagnoser, utredninger og behandlinger. Kunnskaper og ferdigheter utover dette er positivt, men ikke noe vi bør kreve av alle. Dermed er det et lineært forhold mellom hvor mye du kan og vet og hvor faglig dyktig du er.

Vi vil hevde at det langt fra er nok. I legeyrket kan vi få ta del i svært private sfærer av folks liv. Leger har et særlig ansvar for å ivareta mennesker i sårbare situasjoner. Slike møter kan være skremmende, men også givende. Vår evne til å lytte, vise forståelse, ha empati og gi trygghet står sentralt og må oppøves (2). Disse egenskapene er det krevende å tilegne seg, og de kan ikke måles like enkelt som teknisk kompetanse. De læres best i praksis, på visitten, i poliklinikken eller på fastlegekontoret - alltid under kyndig veiledning.

Charlotte Haug, tidligere sjefredaktør i Tidsskriftet, skrev om faglighet slik: «Det er som kvalitetsbegrepet: Vanskelig å definere, men lett å oppdage når det mangler» (3). Vi skulle ønske vi var enige, men $u$ faglighet er ikke alltid enkelt å legge merke til. Hvis legen er svært dyktig til enkelte av sine oppgaver, kan det tilsløre at hun svikter på andre områder. Uheldige væremåter i klinikken kan bestå med eller uten aksept i kollegiet.

Ufaglighet som aksepteres eller ignoreres av andre, er det spesielt krevende å oppdage. Vi er alle flokkdyr, dermed kan ufaglighet smitte. Hva vi definerer som faglig dyktighet, får betydning for hvordan vi utfører våre arbeidsoppgaver og til sist hva slags lege vi tilstreber å være. Derfor er en gjennomtenkt forståelse av faglighet er viktig. Først da kan vi oppdage ufagligheten.

\section{Flinke leger?}

Vi leger liker å være flinke, og «flinkhetens logikk» handler om å opphøye det som er enkelt å måle. Det er trolig derfor vi berømmer den legen som kan ramse opp doseringer og behandlingsforløp. Forstå oss rett - den dyktige legen trenger tillært medisinsk kunnskap og teknisk fingerspisskompetanse, det er det ingen tvil om. Imidlertid trenger hun noe mer for å være faglig dyktig - mer spesifikt egenskaper som eksempelvis empati, pragmatisme, trygghet, beslutsomhet, dedikasjon og klokskap.

Vårt inntrykk er at slike egenskaper ofte ikke tas med i dyktighetsregnskapet i medisinerutdanningen og legejobben. Det er synd hvis profesjonell oppførsel og huma-

\section{«Hvis vi utelukkende} fremelsker egenskaper som i stor grad kan automatiseres, truer vi den fremtidige legerollen»

nistiske trekk ved legegjerningen glemmes i faglighetsregnestykket fordi det tar lengre tid å oppdage, er lite målbart og dårlig egnet for rangering.

Vi har beskrevet to konkurrerende forståelser av faglig dyktighet. En smal forståelse, som innebærer stor grad av boklig lærdom og teknisk fingerspisskompetanse, og en vid forståelse, som $i$ tillegg omfatter egenskaper som gjør det mulig for oss å forstå og behandle pasienten bedre. Vi kan se for oss flere innvendinger til denne vide forståelsen av faglighet. Her tar vi for oss noen av dem.

Den første: Som leger gjør vi viktige prioriteringer, som karikert kan se slik ut: «Når alt kommer til alt, handler legerollen om å stille rett diagnose og gi pasienten korrekt behandling.» Er dette nok? Det er ikke alltid gitt hva korrekt diagnose eller behandling er. Og hvordan pasienten selv opplever legemøtet og hva han ønsker, betyr mye, også for behandlingen. Det kreves ofte stor kløkt for å finne ut av «hva som er til pasientens beste». Dessuten - hvis vi lar pasienten snakke fritt og lytter aktivt, kommer vi trolig i det fleste tilfeller raskere frem til riktig diagnose (4).

Den andre: «Vi bør velge den kalde og kunnskapsrike legen fremfor den varme og kunnskapsløse.» Hvem vil vel ikke foretrekke dr. House fremfor dr. Dyregod? I den virkelige verden er dette neppe noen nødvendig prioritering, siden det trolig ikke finnes noen negativ korrelasjon mellom intel- ligens og empati. Den faglig dyktige legen må utøve og øve på alle sider ved sitt virke.

Den tredje: Noen vil kanskje innvende at faglig dyktighet er forbeholdt de mest «erfarne» legene. Er det en kausal sammenheng mellom antall timer på jobb og faglig dyktighet? Resultatene til Hertzberg og medarbeidere viser blant annet at legene selv mener en god lege er dedikert og at faglig dedikasjon måles $\mathrm{i}$ hvor mye legen er på jobb og hvor effektiv hun er (5). Stemmer dette, vil de eldste vinne fordi de har mest erfaring. Men erfaring uten refleksjon blir ikke nødvendigvis til forbedring, det kan like godt befeste uvaner. Fortiden vet ikke alltid best.

Vi kan definere faget vårt på mange måter, men å redusere det til ren fysiologi, algoritmepugging, diagnosekriterier eller prosedyrer er lite nyttig. Det frarøver oss muligheten til å utøve yrket på en god måte. Det frarøver også pasienten faglig dyktige leger. Hvis vi utelukkende fremelsker egenskaper som i stor grad kan automatiseres, truer vi den fremtidige legerollen $(6,7)$.

Medisinen befinner seg i skjæringspunktet mellom flere fag (8). Det er innslag av naturvitenskap, samfunnsvitenskap og humaniora - og ikke minst mye erfaring og klokskap. Â være en faglig dyktig lege er dermed vanskelig, men ikke umulig. Et skritt på veien er å diskutere hva vi ønsker at medisinsk faglighet $b ø r$ være? Den faglige dyktige legen har mange egenskaper som bør trenes fra første dag på studiet og gjennom hele yrkeskarrieren, og som ikke må glemmes eller nedprioriteres fordi de ikke kan måles like godt eller enkelt som annen dyktighet.

Vi takker legene Esperanza Diaz, Anne Berit Guttormsen, Yngvild Skåtun Hannestad og Jørgen Østensjø for konstruktive kommentarer til tidligere versjoner av denne teksten.

\section{Karl Erik Müller}

karl.muller@uib.no

Ingrid Neteland

Carl Tollef Solberg

Karl Erik Müller (f. 1982) er lege og stipendiat ved Klinisk Institutt II, ved Universitet i Bergen og ved Universitetet i São Paulo, Brasil. Han har arbeidet med profesjonalitetsundervisning på medisinstudiet i Bergen. Müller har i tillegg en bachelorgrad i samfunnsøkonomi fra Storbritannia.

Forfatter har fylt ut ICMJE-skjemaet og oppgir ingen interessekonflikter. 
Ingrid Neteland (f. 1987) er lege i spesialisering i barnesykdommer ved Drammen sykehus. Hun har arbeidet med profesjonalitetsundervisning på medisinstudiet i Bergen og har i en årrekke vært en aktiv debattant omkring kommunikasjon, profesjon og trivsel i medisinerstudentmiljøet og legestanden.

Forfatter har fylt ut ICMJE-skjemaet og oppgir ingen interessekonflikter.

Carl Tollef Solberg (f. 1988) er lege, filosof og stipendiat ved Institutt for global helse og samfunnsmedisin ved Universitetet i Bergen. Han har i perioder vært gjesteforsker ved Universitetet i Oslo og Oxford University.

Forfatter har fylt ut ICMJE-skjemaet og oppgir ingen interessekonflikter.

\section{Litteratur}

1. Hertzberg TK, Skirbekk H, Tyssen R et al. Den gode legen - sterk og utholdende. Tidsskr Nor Legeforen 2016: 136: 1631-4.

2. Paus ASM, Neteland I, Valestrand EA et al. Profesjonalitet kommer ikke av seg selv. Tidsskr Nor Legeforen 2014; 134: 1482-3.

3. Haug C. Medisinsk faglighet. Tidsskr Nor Lægeforen 2006: 126: 125

4. Gulbrandsen P. God kommunikasjon - også for legenes skyld! Tidsskr Nor Legeforen 2008; 128 2840-2.

5. Hertzberg TK, Skirbekk H, Tyssen R et al. Dagens sykehuslege - fremdeles alltid på vakt. Tidsskr Nor Legeforen 2016; 136: 1635-8.

6. Armstrong $\mathrm{S}$. The computer will assess you now. BMJ 2016; 355: i5680

7. Ladher N. Rise of the machines. BMJ 2016; 355: i5777.

8. Müller KE, Solberg CT. Student Research in the Medical Curriculum: Experiences From Norway. Acad Med 2017: 92: 431.

Mottatt 30.1. 2017, første revisjon innsendt 9.3. 2017, godkjent 18.4. 2017. Redaktør: Kaveh Rashidi.

果 Engelsk oversettelse på www.tidsskriftet.no

Publisert først på nett. 